\title{
Fusarium Secondary Metabolite Content in Naturally Produced and Artificially Provoked FHB Pressure in Winter Wheat
}

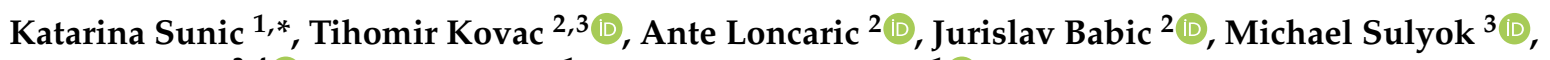 \\ Rudolf Krska ${ }^{3,4}\left(\right.$, Georg Drezner ${ }^{1}$ and Valentina Spanic ${ }^{1}(\mathbb{C}$
}

1 Department of Small Cereal Crops, Agricultural Institute Osijek, 31000 Osijek, Croatia; georg.drezner@poljinos.hr (G.D.); valentina.spanic@poljinos.hr (V.S.)

2 Faculty of Food Technology Osijek, Josip Juraj Strossmayer University of Osijek, 31000 Osijek, Croatia; tihomir.kovac@ptfos.hr (T.K.); ante.loncaric@ptfos.hr (A.L.); jbabic@ptfos.hr (J.B.)

3 Department of Agrobiotechnology (IFA-Tulln), Institute of Bioanalytics and Agro-Metabolomics, University of Natural Resources and Life Sciences Vienna (BOKU), 3430 Tulln, Austria; michael.sulyok@boku.ac.at (M.S.); rudolf.krska@boku.ac.at (R.K.)

4 Institute for Global Food Security, School of Biological Sciences, Queen's University Belfast, University Road, Belfast BT7 1NN, UK

* Correspondence: katarina.sunic@poljinos.hr; Tel.: +385-31-515-545

check for updates

Citation: Sunic, K.; Kovac, T.; Loncaric, A.; Babic, J.; Sulyok, M.; Krska, R.; Drezner, G.; Spanic, V. Fusarium Secondary Metabolite Content in Naturally Produced and Artificially Provoked FHB Pressure in Winter Wheat. Agronomy 2021, 11, 2239. https://doi.org/10.3390/ agronomy11112239

Academic Editor: Katja Witzel

Received: 16 September 2021

Accepted: 30 October 2021

Published: 4 November 2021

Publisher's Note: MDPI stays neutral with regard to jurisdictional claims in published maps and institutional affiliations.

Copyright: (c) 2021 by the authors. Licensee MDPI, Basel, Switzerland. This article is an open access article distributed under the terms and conditions of the Creative Commons Attribution (CC BY) license (https:/ / creativecommons.org/licenses/by/ $4.0 /)$.

\begin{abstract}
Fusarium head blight (FHB) is an important disease of wheat and production of mycotoxins makes it a major threat in most wheat-producing areas worldwide. This study aimed to identify the impact of epidemic FHB conditions (usage of artificial Fusarium inoculation) on mycotoxin levels in unprocessed wheat. Fusarium levels were monitored at two locations in two treatments (natural infection and inoculation with Fusarium graminearum and F. culmorum) where 13 mycotoxins were evaluated by LC/MS-MS in six winter wheat varieties. Due to favorable conditions for infection with Fusarium fungi during the flowering period at location Tovarnik, wheat varieties had higher disease severity and increased mycotoxin accumulation, compared to Osijek. The most abundant mycotoxins in treatment with inoculation with Fusarium fungi were deoxynivalenol (DON), culmorin (CUL) and hydroxyculmorins. In treatment with natural infection, DON did not exceed maximum limits set by EU. Varieties with lower initial resistance accumulated DON even in naturally infected samples at Tovarnik. These results highlighted the impact of environment variation in the production of Fusarium mycotoxins where FHB initial resistance had a higher impact on the accumulation of mycotoxins than general resistance. Furthermore, wheat samples with higher DON concentration also contained elevated levels of CUL and hydroxyculmorins, showing that CUL can have a possible role in Fusarium virulence. The FHB evaluations provide important information about the genetic resistance of wheat varieties, as well as risk assessment considering mycotoxin accumulation in epidemic conditions.
\end{abstract}

Keywords: Fusarium culmorum; Fusarium graminearum; mycotoxins; wheat; LC/MS-MS

\section{Introduction}

Wheat is one of the major staple and one of the "big three" cereal crops with an annual worldwide production of over 600 million tons [1]. During the period of anthesis, the plant is the most susceptible to diseases that affect wheat heads and one of the main concerns is Fusarium head blight (FHB) caused by fungi of the genus Fusarium. The disease can result in direct and indirect economic losses thus causing reduced grain yield and quality, as well as production of mycotoxins [2].

A wide range of factors play different roles in the growth, survival and dissemination of the fungus and thus can influence disease severity and mycotoxin production [3]. Primarily, the aggressiveness of Fusarium species and accumulation of mycotoxins is determined by wheat genetic variation [4]. The presence and incidence of different Fusarium 
species in the crop affect the mycotoxin profile and contamination of the grain [5]. Fusarium graminearum and F. culmorum are the most dominant and prevalent species causing FHB worldwide, as well as in Croatia [6], where they can be highly aggressive and can produce abundant mycotoxins. Several other species like F. poae and F. avenaceum, which are also frequently found in winter wheat in East Croatia, are less pathogenic [6,7]. However, less aggressive species are still of great concern since their development with other more aggressive pathogens can also lead to the accumulation of mycotoxins, even if the symptoms of the disease are not expressed to such an extent [2]. Another factor influencing mycotoxin content are optimal climatic conditions for disease development, namely temperature and water availability, which depend on the local and regional environment. Most studies reported that an environment with frequent rainfall and warm temperatures favours the disease development and thus the production of mycotoxins [2,8,9]. Previously it was reported that the influence of climatic conditions on the accumulation of mycotoxins most probably is an indirect factor, influencing primarily fungal growth [3]. However, disease development depends on the substrate, Fusarium species present and individual metabolite since every species of FHB complex have different environmental demands. Moderate temperatures and lower water availability favour the production of type A trichothecenes by F. sporotrichioides, while warmer humid conditions induce the production of type B trichothecenes by F. culmorum and F. graminearum [3]. Other studies also reported that the wheat grain contamination with mycotoxins was highly correlated with relative humidity and sum of precipitation in short period around anthesis, namely five day pre-anthesis period, while correlation coefficients for post-anthesis periods showed lower significance [10]. Strong correlation between precipitation during the period of anthesis and infection by the Fusarium fungi occurred in some researches [11]. Generally, mycotoxin production by $F$. graminearum and F. culmorum seems to be stimulated by narrower weather conditions than that for growth [12].

There are different types of resistance to FHB in wheat: type I (resistance to initial infection), type II (resistance to disease spread), type III (re-sistance to kernel infection), type IV (tolerance) and type V (resistance to mycotoxins) [13]. Mycotoxins produced by Fusarium species pose a threat to both, animal and human health [14]. One of the most abundant mycotoxins and therefore most frequently contaminating grains and food products is deoxynivalenol (DON) [8]. Together with its acetylated forms, 3-acetyldeoxynivalenol (3ADON), 15-acetyldeoxynivalenol (15ADON), deoxynivalenol-3-glucoside (D3G), as well as nivalenol (NIV), belong to trichothecenes group B. DON is also known as vomitoxin considering its emetic effect [15]. Watching from the aspect of the cell DON is a potent inhibitor of protein synthesis and some of the mechanisms occurring in response to high DON concentrations involve inflammatory processes, diarrhea, lack of appetite as well as necrosis of certain tissues [14,16]. Nivalenol (NIV) is the mycotoxin mainly produced by F. graminearum, F. culmorum and F. poae [17]. Although there is still scarce evidence of its effect on humans [18], some studies have found that NIV interferes with the synthesis of nucleic acids, induces programmed cell death in vitro and causes immuno- and hematotoxicity in animals. Zearalenone $(\mathrm{ZEN})$ is non-steroidal estrogenic mycotoxin that may cause hyperestrogenism and infertility and even low concentrations can influence the hormonal balance in mammals [14,19]. Main Fusarium species known to produce ZEN are F. graminearum, F. culmorum, F. crookwellense, F. semitectum and F. equiseti [20]. Only a few mycotoxins are regulated and monitored by European Union (EU), while many of them are indicated as "emerging" [21]. In addition to these better-known compounds, other Fusarium metabolites require more investigation. Culmorin (CUL), a metabolite that gains a lot of scientific attention, is a tricyclic sesquiterpene diol. According to studies, it does not affect insects or animals [22]. However, recent findings indicated that interactions of CUL and DON increase phytotoxicity levels, namely by CUL inhibiting glycosylation of DON into less toxic DON 3-O-glucose [15,22,23]. Another mycotoxin that acquires more scientific investigation since it is highly mutagenic in in vitro bioassays is fusarin $\mathrm{C}$. It was first isolated from Fusarium moniliforme [24]. However, the exact role of fusarin C on 
human and animal health has not yet been described [19]. Butenolide (BUT) is a mycotoxin produced by Fusarium graminearum and other Fusarium species [19]. It is associated with cattle mycotoxicosis called "fescue foot" which can result in edema and gangrenous loss of extremities [19]. Some studies have reported its involvement in Kashin-Beck disease and Keshan disease in China [25]. Despite a fact that aurofusarin is a pigment with antibiotic effect, it was found that aurofusarin can also induce oxidative stress and cytotoxicity in human colon cells [26]. Chrysogin so far has no report on its effect on human and animal health in the scientific literature [5].

Only a small portion of the mycotoxins studied are regulated and for the majority to date, no regulations exist. Therefore, it is necessary to obtain more data on these mycotoxins. Considering the findings of harmful mycotoxin effects on human and animal health, the aim of this study was to estimate the effect of epidemic FHB conditions on mycotoxin levels in artificially inoculated winter wheat, as well as in naturally infected samples.

\section{Materials and Methods}

\subsection{Plant Material and Field Trials}

The study was conducted in vegetative season 2019/2020 at two locations, Osijek $\left(45^{\circ} 32^{\prime} \mathrm{N}, 18^{\circ} 44^{\prime} \mathrm{E}\right)$ and Tovarnik $\left(45^{\circ} 10^{\prime} \mathrm{N}, 19^{\circ} 09^{\prime} \mathrm{E}\right)$, Croatia. The soil types in these two regions are different with eutric cambisol present at Osijek and black soil chernozem at Tovarnik. During the period of flowering, the average precipitation was $1.7 \mathrm{~mm}$ at Osijek (Supplementary Table S1, Figure S1) and $2.3 \mathrm{~mm}$ at Tovarnik (Supplementary Table S2, Figure S2), and the average temperature was $15.3^{\circ} \mathrm{C}$ at Osijek (Supplementary Table S3, Figure S1) and $15.6{ }^{\circ} \mathrm{C}$ at Tovarnik (Supplementary Table S4, Figure S2). The experimental plot area was $7.56 \mathrm{~m}^{2}$, where treatments (naturally infected and artificially inoculated) were replicated in two plots. In each treatment, same winter wheat varieties (El Nino, Galloper, Tika Taka, Vulkan, Kraljica and Golubica) originated from Agricultural institute Osijek, were used. The seed was treated with Vitavax $200 \mathrm{FF}$ (thiram + carboxin) at a rate of $200 \mathrm{~g}$ Vitavax for $100 \mathrm{~kg}$ of seeds in order to control seed-borne diseases. Fungicides were excluded in both treatments and in the both investigated environments. Weed control was conducted with a herbicide at wheat tillering (GS 31). Insecticides were sprayed in the spring of the growing season. Fertilization was in proportions N:P:K 130:100:120 kg ha-1. The grains were taken by harvesting the whole plot with a Wintersteiger cereal plot combine-harvester.

\subsection{Inoculum Preparation and Inoculation Procedure}

The Fusarium species used in this experiment were the two most prevalent causal agents of Fusarium head blight: Fusarium graminearum (PIO 31), isolated from the winter wheat collected in East Croatia, and F. culmorum (IFA 104) obtained from IFA-Tulln, Austria. Conidial inoculum of Fusarium spp. were produced by a mixture of wheat and oat grains ( $3: 1$ by volume). Conidial concentrations of both fungi were determined using a hemocytometer (Bürker-Türk, Hecht Assistent) and were set to $10 \times 10^{4} \mathrm{~mL}^{-1}$. The $100 \mathrm{~mL}$ of inoculum was sprayed with sprayers on an area of $\mathrm{m}^{2}$ at the flowering stage. One treatment was grown according to standard agronomical practice with no usage of fungicide and without misting treatment, while another treatment was subjected to two inoculation events using a tractor-back (Osijek) and hand sprayer (Tovarnik) with Fusarium spp. at the time of flowering (Zadok's scale 65) [27] (Figure 1a). Misting was provided by spraying with a tractor back-sprayer on several occasions. 


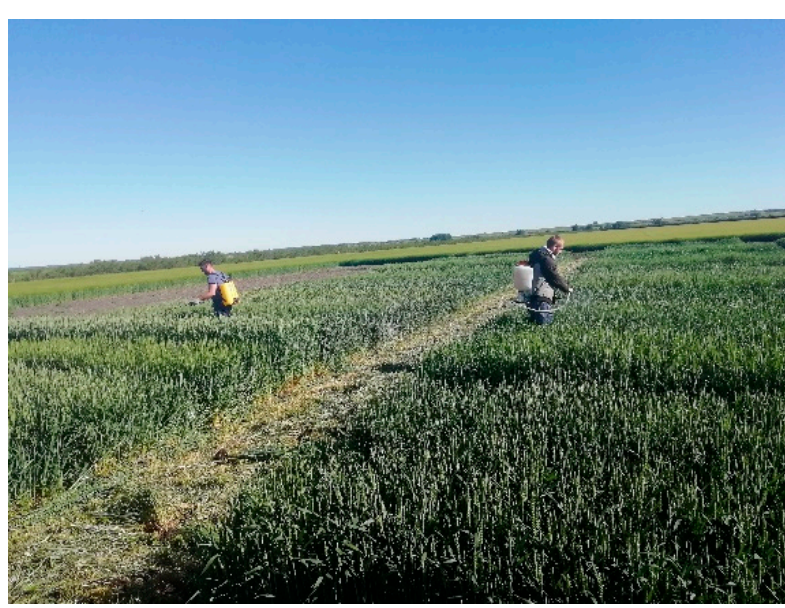

(a)

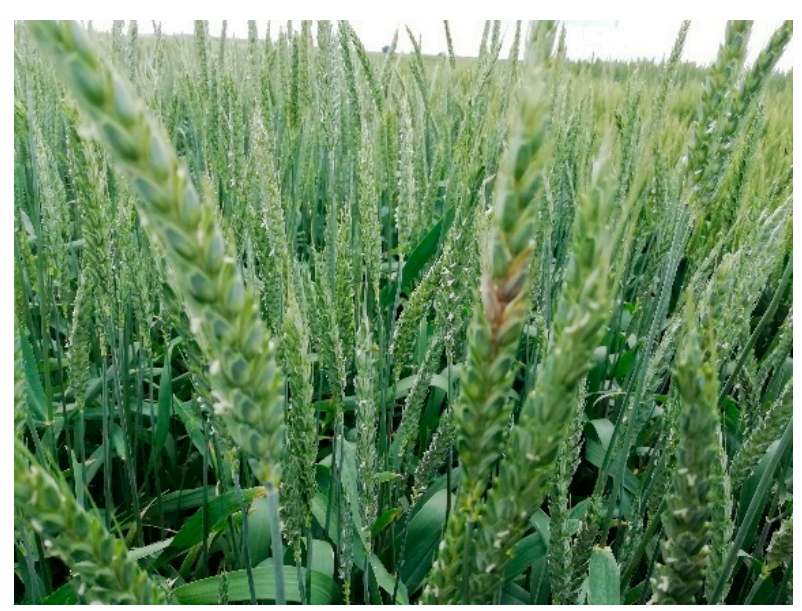

(b)

Figure 1. Inoculation spraying at Tovarnik (a) and the first visible symptoms of the wheat heads seen as bleaching of the spikeletes (b).

\subsection{Fusarium General Resistance and Type I Resistance}

The percentage of bleached spikelets (Figure $1 \mathrm{~b}$ ) per plot and initial infection were estimated on days $10,14,18,22$, and 26 after inoculation according to a linear scale ( $0-100 \%)$. Based on the percentages, the area under the disease progress curve (AUDPC) for general resistance and type I FHB resistance of wheat varieties was calculated according to formula:

$$
A U D P C=\sum_{i=1}^{n}\left\{\left[\frac{Y i+Y i-1}{2}\right] *(X i-X i-1)\right\}
$$

where $Y i$ is percentage of visibly infected spikelets $(Y i / 100)$ at the $i$ th observation, $X i$ is day of the $i$ th observation and $n$ is total number of observations.

\subsection{Mycotoxin Analysis}

Determination of mycotoxin was performed by LC-MS/MS [28]: $5 \mathrm{~g}$ of wheat (previously ground by IKA M20, IKA, Staufen, Germany) were extracted using $20 \mathrm{~mL}$ extraction solvent (acetonitrile-water-acetic acid, 79:20:1, $v / v / v$ ) followed by a $1+1$ dilution using acetonitrile-water-acetic acid, $(20: 79: 1, v / v / v)$ and direct injection of $5 \mu \mathrm{L}$ diluted extract. LC-MS/MS screening of target fungal metabolites was performed with a QTrap 5500 LCMS/MS System (Applied Biosystems, Foster City, CA, USA) equipped with a Turbolon Spray electrospray ionization (ESI) source and a 1290 Series HPLC System (Agilent, Waldbronn, Germany). Chromatographic separation was performed at $25^{\circ} \mathrm{C}$ on a Gemini ${ }^{\circledR}$ C18-column, $150 \times 4.6 \mathrm{~mm}$ i.d., $5 \mu \mathrm{m}$ particle size, equipped with a C18 $4 \times 3 \mathrm{~mm}$ i.d. security guard cartridge (all from Phenomenex, Torrance, CA, USA).

Confirmation of positive analyte identification was obtained by the acquisition of two MRMs per analyte (with the exception of moniliformin and 3-nitropropionic acid that exhibit only one fragment ion), which yielded 4.0 identification points according to commission decision [29]. In addition, the liquid chromatography retention time and the intensity ratio of the two MRM transitions agreed with the related values of an authentic standard within $0.03 \mathrm{~min}$ and $30 \%$ rel., respectively. Quantification was performed via external calibration using serial dilutions of a multi-analyte stock solution. Results were corrected for apparent recoveries obtained for wheat [28] (Supplementary Tables S5-S9). The accuracy of the method is verified on a continuous basis by regular participation in proficiency testing scheme organized by BIPEA (Gennevilliers, France). 


\subsection{Statistical Analysis}

The data were subjected to analysis of variance (ANOVA) using an appropriate model by Statistica version 12.0 (Statsoft Inc., Tulsa, OK, USA). To estimate disease progress, the AUDPC was used to combine multiple observations from five data points (different dates) into a single value. For correlation analyses, Spearman's coefficient was applied, shown in the supplementary file.

\section{Results}

\subsection{Fusarium General Resistance and Type I Resistance}

The FHB symptoms varied among locations, where at Tovarnik there was higher area under the disease progress curve (AUDPC) for general resistance on average for three varieties (El Nino, Galloper and Tika Taka), compared to Osijek. The highest Type I and general resistance at Osijek had Galloper, as well as general resistance at Tovarnik. The lower AUDPC for initial resistance (higher Type I resistance) had Vulkan and Kraljica at Tovarnik. The highest AUDPC for Type I resistance was recorded for El Nino (AUDPC 421) at Tovarnik, followed by Golubica at Osijek (AUDPC 222) (Table 1).

Table 1. Area under the disease progress curve (AUDPC) for general resistance and Type I resistance (initial infection) to Fusarium head blight (FHB) at locations Osijek and Tovarnik and their standard deviations (SD).

\begin{tabular}{ccccc}
\hline Variety & $\begin{array}{c}\text { AUDPC for } \\
\text { General } \\
\text { Resistance } \\
\text { Osijek } \pm \text { SD }\end{array}$ & $\begin{array}{c}\text { AUDPC for } \\
\text { General } \\
\text { Resistance } \\
\text { Tovarnik } \pm \text { SD }\end{array}$ & $\begin{array}{c}\text { AUDPC for } \\
\text { Type I } \\
\text { Resistance } \\
\text { Osijek } \pm \text { SD }\end{array}$ & $\begin{array}{c}\text { AUDPC for } \\
\text { Type I } \\
\text { Resistance } \\
\text { Tovarnik } \pm \text { SD }\end{array}$ \\
\hline El Nino & $137.3 \pm 10.75$ & $212.5 \pm 142.5$ & $244 \pm 40$ & $421 \pm 212.5$ \\
Galloper & $1.3 \pm 0$ & $17.5 \pm 9.5$ & $33.1 \pm 16.63$ & $87.4 \pm 25.85$ \\
Tika Taka & $42.7 \pm 11.35$ & $69.8 \pm 7.25$ & $215.3 \pm 74.7$ & $137.6 \pm 41.95$ \\
Vulkan & $35.8 \pm 6.25$ & $33.8 \pm 5.25$ & $119.9 \pm 11.35$ & $50.6 \pm 4.1$ \\
Kraljica & $71.5 \pm 23.5$ & $18.3 \pm 1.75$ & $216.5 \pm 80.5$ & $80.1 \pm 10.4$ \\
Golubica & $103.8 \pm 22.75$ & $93 \pm 7$ & $222.3 \pm 29.2$ & $111.3 \pm 8.3$ \\
\hline
\end{tabular}

\subsection{Mycotoxin Analysis}

3.2.1. Deoxynivalenol, Deoxynivalenol-3-glucoside and 3-Acetyldeoxynivalenol

The concentrations of deoxynivalenol (DON), deoxynivalenol-3-glucoside (D3G) and $3 \mathrm{ADON}$ were elevated in Fusarium infected samples, compared to naturally infected samples of all winter wheat varieties tested. DON was one of the most abundant mycotoxins produced in artificially inoculated treatment at Osijek and Tovarnik. D3G and 3ADON were also found in all Fusarium infected samples at both locations. The levels of DON measured in six artificially inoculated samples at Osijek were $5410 \mathrm{\mu g} \mathrm{kg}^{-1}$ in Galloper, $6370 \mu \mathrm{g} \mathrm{kg}{ }^{-1}$ in Kraljica, $6740 \mu \mathrm{g} \mathrm{kg}{ }^{-1}$ in Vulkan, $17,700 \mu \mathrm{g} \mathrm{kg}{ }^{-1}$ in Tika Taka, $18,300 \mu \mathrm{g} \mathrm{kg}^{-1}$ in El Nino and 22,800 $\mathrm{g} \mathrm{kg}^{-1}$ in Golubica (Figure 2a) and at Tovarnik $13,200 \mu \mathrm{g} \mathrm{kg}^{-1}$ in Vulkan, 13,400 $\mu \mathrm{g} \mathrm{kg}^{-1}$ in Galloper, $19,800 \mu \mathrm{g} \mathrm{kg}^{-1}$ in Kraljica, $21,000 \mu \mathrm{g} \mathrm{kg}^{-1}$ in Tika Taka, 21,100 $\mu \mathrm{g} \mathrm{kg}^{-1}$ in El Nino and 25,500 $\mu \mathrm{g} \mathrm{kg}^{-1}$ in Golubica (Figure 2b). The highest concentration of DON in naturally infected samples at Tovarnik was recorded in El Nino variety $\left(620 \mu \mathrm{g} \mathrm{kg}^{-1}\right)$ and the lowest in Kraljica $\left(19 \mu \mathrm{g} \mathrm{kg}^{-1}\right)$. 
a) 25,000

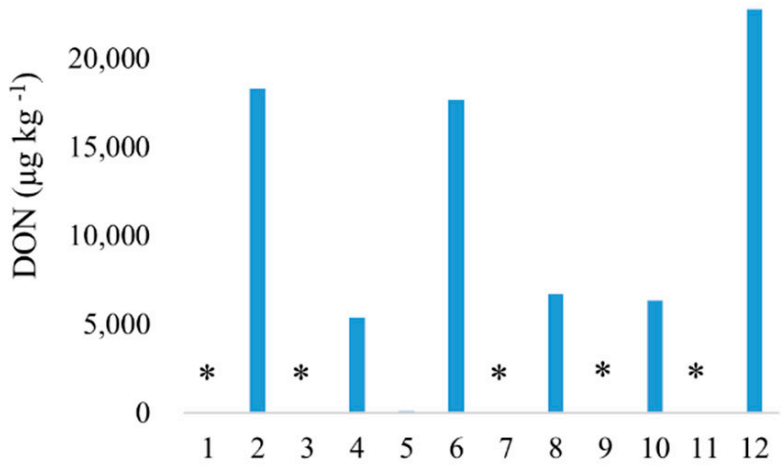

c) 800

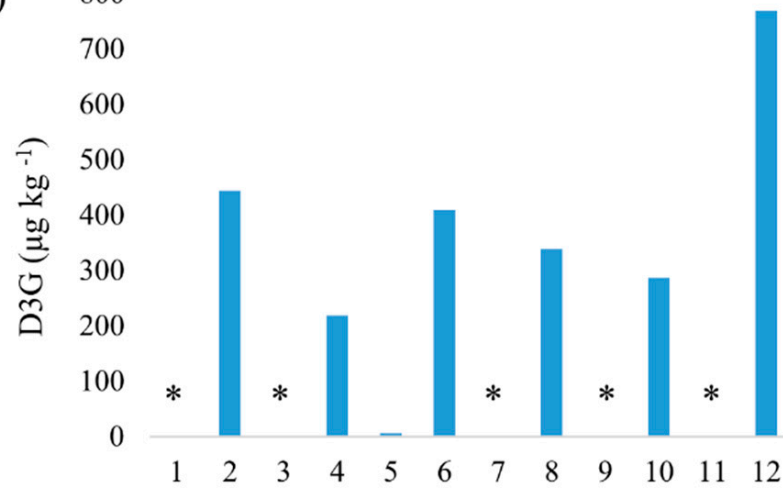

e) 1,200

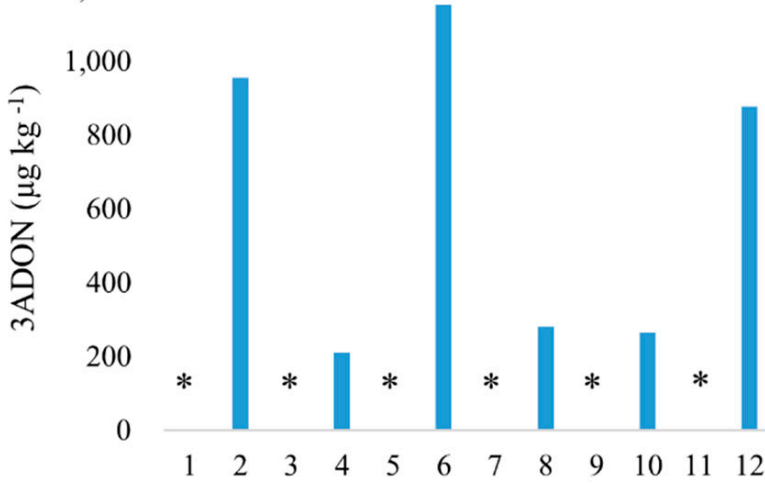

b) 30,000

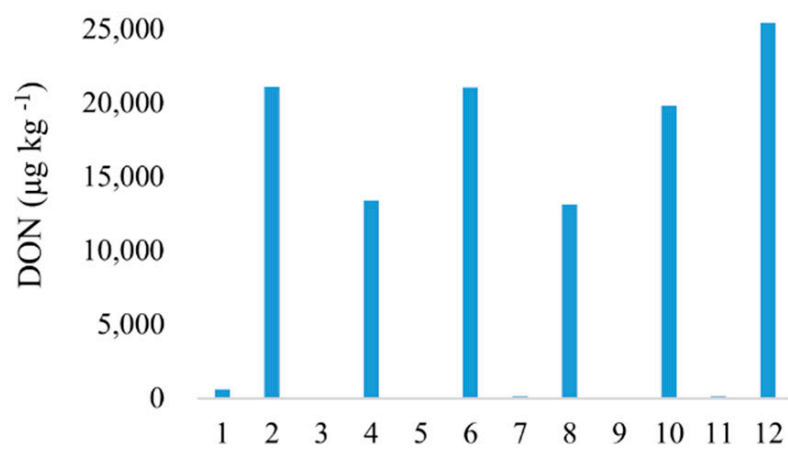

d) 800

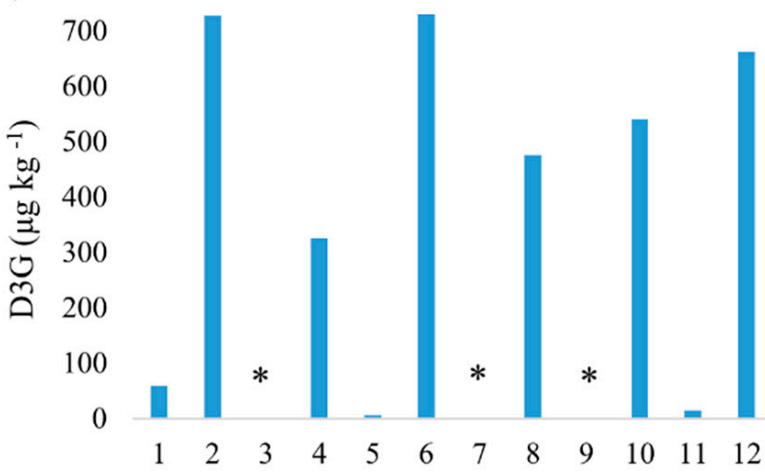

f) 2,000

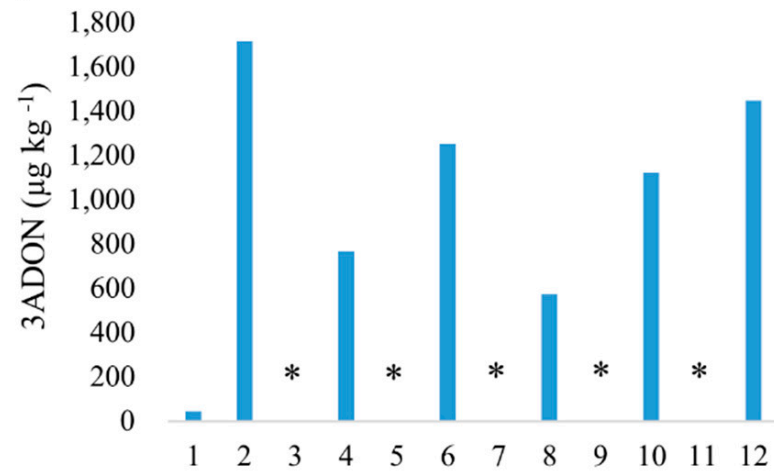

1 - El Nino - naturally infected

2 - El Nino - inoculated

3 - Galloper - naturally infected

4 - Galloper - inoculated

5 - Tika Taka - naturally infected

6 - Tika Taka - inoculated
7 - Vulkan - naturally infected

8 - Vulkan - inoculated

9 - Kraljica - naturally infected

10 - Kraljica - inoculated

11 - Golubica - naturally infected

12 - Golubica - inoculated

Figure 2. Concentrations of deoxynivalenol (DON) (a,b), deoxynivalenol-3-glucoside (D3G) (c,d) and 3-acetylde- oxynivalenol $(3 \mathrm{ADON})(\mathbf{e}, \mathbf{f})$ in artificially inoculated and naturally infected samples at Osijek $(\mathbf{a}, \mathbf{c}, \mathbf{e})$ and Tovarnik $(\mathbf{b}, \mathbf{d}, \mathbf{f})$. The asterisk $\left(^{*}\right)$ indicates that measured values are below LOD values.

Concentrations of D3G and 3ADON were lower than the concentrations of DON. D3G ranged from $219 \mu \mathrm{g} \mathrm{kg}^{-1}$ to $770 \mu \mathrm{g} \mathrm{kg}^{-1}$ at Osijek (Figure 2c) and from $326 \mu \mathrm{g} \mathrm{kg}^{-1}$ to $731 \mu \mathrm{g} \mathrm{kg}^{-1}$ at Tovarnik (Figure 2d), while 3ADON at Osijek ranged from $212 \mu \mathrm{g} \mathrm{kg}^{-1}$ to $1150 \mu \mathrm{g} \mathrm{kg}^{-1}$ (Figure 2e) and at Tovarnik from $572 \mu \mathrm{g} \mathrm{kg}^{-1}$ to $1720 \mu \mathrm{g} \mathrm{kg}^{-1}$ (Figure 2f). 


\subsubsection{Nivalenol and Zearalenone}

Concentrations of nivalenol (NIV) and zearalenone (ZEN) were lower than the rest of the Fusarium metabolites studied at both locations. At Osijek, NIV was found only in artificially inoculated samples of most FHB susceptible varieties (El Nino, Tika Taka and Golubica) where the levels were $29 \mu \mathrm{g} \mathrm{kg}^{-1}, 31 \mu \mathrm{g} \mathrm{kg}^{-1}$ and $37 \mu \mathrm{g} \mathrm{kg}^{-1}$, respectively (Figure 3a). At Tovarnik, NIV was found in all artificially inoculated samples and the concentrations ranged from $24 \mu \mathrm{g} \mathrm{kg}^{-1}$ in Galloper to $105 \mu \mathrm{g} \mathrm{kg}^{-1}$ in Golubica with an overall mean of $44 \mathrm{\mu g} \mathrm{kg}^{-1}$ (Figure 3b). In naturally infected samples it was detected only in Golubica $\left(70 \mu \mathrm{g} \mathrm{kg}^{-1}\right)$.
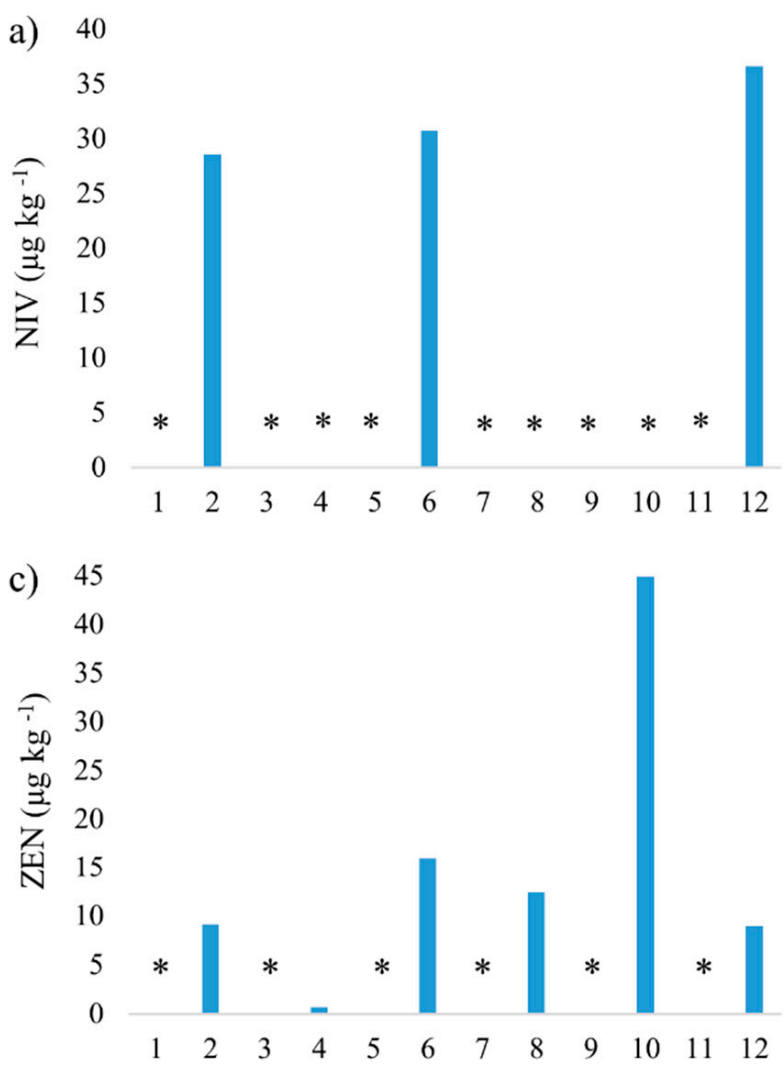

b) 120

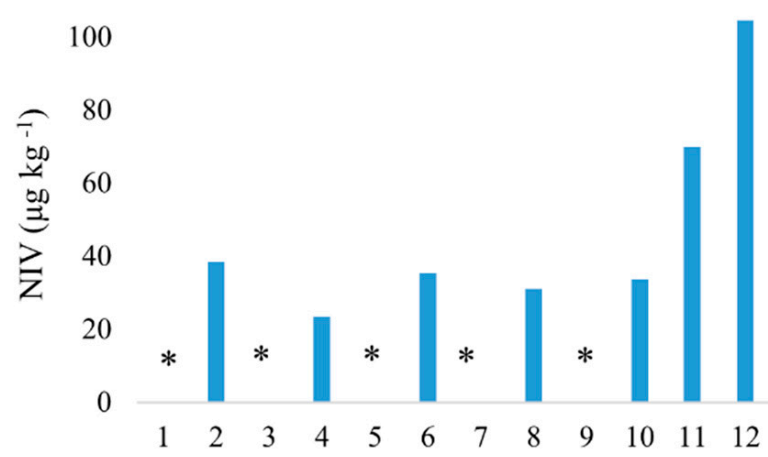

d) 60

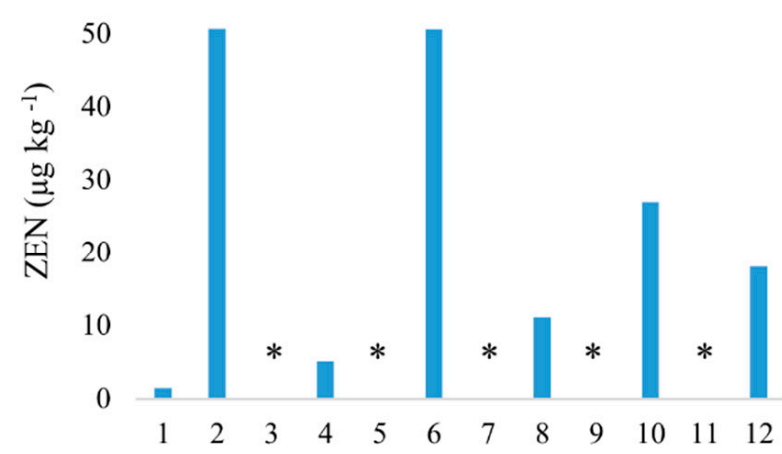

1 - E1 Nino - naturally infected

2 - El Nino - inoculated

3 - Galloper - naturally infected

4 - Galloper - inoculated

5 - Tika Taka - naturally infected

6 - Tika Taka - inoculated
7 - Vulkan - naturally infected

8 - Vulkan - inoculated

9 - Kraljica - naturally infected

10 - Kraljica - inoculated

11 - Golubica - naturally infected

12 - Golubica - inoculated

Figure 3. Concentrations of nivalenol (NIV) $(\mathbf{a}, \mathbf{b})$ and zearalenone (ZEN) (c,d) in artificially inoculated and naturally infected samples at Osijek $(\mathbf{a}, \mathbf{c})$ and Tovarnik $(\mathbf{b}, \mathbf{d})$. The asterisk $\left(^{*}\right)$ indicates that measured values are below LOD values.

All artificially inoculated samples at both locations were contaminated with ZEN. None of the naturally infected samples contained ZEN except the El Nino variety at Tovarnik and its concentration was $1 \mu \mathrm{g} \mathrm{kg}^{-1}$. The levels of ZEN measured at artificially inoculated six varieties at Osijek were $1 \mu \mathrm{g} \mathrm{kg}^{-1}$ in Galloper, $9 \mu \mathrm{g} \mathrm{kg}^{-1}$ in Golubica, $9 \mu \mathrm{g} \mathrm{kg}^{-1}$ in El Nino, $12 \mu \mathrm{g} \mathrm{kg}^{-1}$ in Vulkan, $16 \mu \mathrm{g} \mathrm{kg}^{-1}$ in Tika Taka and $45 \mu \mathrm{g} \mathrm{kg}^{-1}$ in Kraljica with an average level of $15 \mu \mathrm{g} \mathrm{kg}^{-1}$ (Figure 3c) and at Tovarnik $5 \mu \mathrm{g} \mathrm{kg}^{-1}$ in Galloper, $11 \mu \mathrm{g} \mathrm{kg}{ }^{-1}$ in Vulkan, $18 \mu \mathrm{g} \mathrm{kg}^{-1}$ in Golubica, $27 \mu \mathrm{g} \mathrm{kg}^{-1}$ in Kraljica, $51 \mu \mathrm{g} \mathrm{kg}^{-1}$ in El Nino and $51 \mu \mathrm{g} \mathrm{kg}^{-1}$ in Tika Taka (Figure 3d) with an average level of $27 \mu \mathrm{g} \mathrm{kg}^{-1}$. 


\subsubsection{Culmorin, 15-Hydroxyculmorin, 15-Hydroxyculmoron and 5-Hydroxyculmorin}

El Nino, Tika Taka and Golubica accumulated culmorin (CUL) and its derivatives in much higher concentrations than other varieties. At Osijek, concentrations of CUL were elevated in the artificially inoculated compared to naturally infected samples. The highest amount of CUL was recorded in an artificially inoculated Golubica variety $\left(29,100 \mu \mathrm{g} \mathrm{kg}^{-1}\right)$. Other concentrations ranged from $7810 \mu \mathrm{g} \mathrm{kg}^{-1}$ in Kraljica to $13,100 \mu \mathrm{g} \mathrm{kg}^{-1}$ in Vulkan. In naturally infected samples CUL was found only in Tika Taka variety at concentration of $220 \mu \mathrm{g} \mathrm{kg}^{-1}$ (Figure 4a). At Tovarnik, concentrations of CUL were elevated even in naturally infected samples. The highest concentration was found in El Nino variety $\left(1000 \mu \mathrm{g} \mathrm{kg}^{-1}\right)$ and the lowest was recorded in Tika Taka variety $\left(62 \mu \mathrm{g} \mathrm{kg}^{-1}\right)$, while in Kraljica it was not found. In artificially inoculated samples concentrations ranged from $6100 \mu \mathrm{g} \mathrm{kg}^{-1}$ in Galloper to $14,300 \mu \mathrm{g} \mathrm{kg}^{-1}$ in Golubica with an overall mean of $11,400 \mu \mathrm{g} \mathrm{kg}^{-1}$ (Figure $4 \mathrm{~b}$ ).

Concentrations of CUL derivatives were also elevated at both locations in Fusarium infected samples compared to naturally-infected. In artificially inoculated samples at Osijek 15-hydroxyculmorin ranged from $8130 \mathrm{\mu g} \mathrm{kg}^{-1}$ to $28,800 \mathrm{\mu g} \mathrm{kg}^{-1}$ (Figure 4c) and at Tovarnik from $15,600 \mu \mathrm{g} \mathrm{kg}^{-1}$ to $27,000 \mu \mathrm{g} \mathrm{kg}^{-1}$ (Figure $4 \mathrm{~d}$ ). 15-hydroxyculmoron was in range from $570 \mu \mathrm{g} \mathrm{kg}^{-1}$ to $4610 \mu \mathrm{g} \mathrm{kg}^{-1}$ (Figure 4e) and from $1200 \mu \mathrm{g} \mathrm{kg}^{-1}$ to $2990 \mathrm{\mu g} \mathrm{kg}^{-1}$ (Figure 4f) for Osijek and Tovarnik, respectively. Regarding 5-hydroxyculmorin at Osijek, it ranged from $5100 \mu \mathrm{g} \mathrm{kg}^{-1}$ to $24,400 \mu \mathrm{g} \mathrm{kg}^{-1}$ (Figure $4 \mathrm{~g}$ ) and at Tovarnik from $14,000 \mu \mathrm{g} \mathrm{kg}^{-1}$ to $30,000 \mu \mathrm{g} \mathrm{kg}^{-1}$ (Figure $4 \mathrm{~h}$ ). No CUL derivatives were found in naturally infected samples at Osijek except for Tika Taka variety which accumulated 15hydroxyculmorin at concentration of $89 \mathrm{\mu g} \mathrm{kg}^{-1}$. At Tovarnik, CUL derivatives were detected not only in artificially inoculated but also in naturally infected samples, as for DON and its derivatives. In naturally infected samples the highest concentrations recorded were $81 \mu \mathrm{g} \mathrm{kg}^{-1}, 637 \mu \mathrm{g} \mathrm{kg}^{-1}$ and $1230 \mu \mathrm{g} \mathrm{kg}^{-1}$ in El Nino variety for 15-hydroxyculmoron, 5-hydroxyculmorin and 15-hydroxyculmorin, respectively.

\subsubsection{Aurofusarin, Butenolide, Chrysogin and Fusarin C}

For other Fusarium metabolites, namely aurofusarin, butenolide, chrysogin and fusarin $\mathrm{C}$ increases were also recorded in Fusarium infected samples compared to naturally infected samples at Osijek and Tovarnik. At Osijek, aurofusarin was recorded in the range from $1870 \mu \mathrm{g} \mathrm{kg}^{-1}$ to $12,511 \mu \mathrm{g} \mathrm{kg}^{-1}$ (Figure 5a). At Tovarnik, aurofusarin levels in artificially inoculated samples were increased, compared to Osijek and the highest concentration was $67,600 \mu \mathrm{g} \mathrm{kg}^{-1}$ in El Nino variety. In addition, aurofusarin was detected only in El Nino even in naturally infected samples $\left(739 \mu \mathrm{g} \mathrm{kg}^{-1}\right.$ ) (Figure 5b). Butenolide levels at Osijek ranged from $167 \mu \mathrm{g} \mathrm{kg}^{-1}$ to $1120 \mu \mathrm{g} \mathrm{kg}^{-1}$ (Figure 5c) and at Tovarnik from $188 \mu \mathrm{g} \mathrm{kg}^{-1}$ to $654 \mu \mathrm{g} \mathrm{kg}^{-1}$ (Figure 5d). At Osijek, chrysogin was recorded in range from $346 \mu \mathrm{g} \mathrm{kg}^{-1}$ to $1320 \mu \mathrm{g} \mathrm{kg}^{-1}$ (Figure 5e) and at Tovarnik from $528 \mu \mathrm{g} \mathrm{kg}^{-1}$ to $1170 \mu \mathrm{g} \mathrm{kg}^{-1}$ (Figure $5 \mathrm{f}$ ). The level of fusarin $C$ at Osijek ranged from $665 \mu \mathrm{g} \mathrm{kg}^{-1}$ to $2660 \mu \mathrm{g} \mathrm{kg}^{-1}$ (Figure $5 \mathrm{~g}$ ) while at Tovarnik it was elevated compared to Osijek and it ranged from $2610 \mu \mathrm{g} \mathrm{kg}^{-1}$ to $6720 \mu \mathrm{g} \mathrm{kg}^{-1}$ (Figure 5h). Butenolide, chrysogin and fusarin C found in artificially inoculated samples were in lower concentrations compared to aurofusarin. Regarding naturally infected samples, only chrysogin was detected in negligible concentrations. 


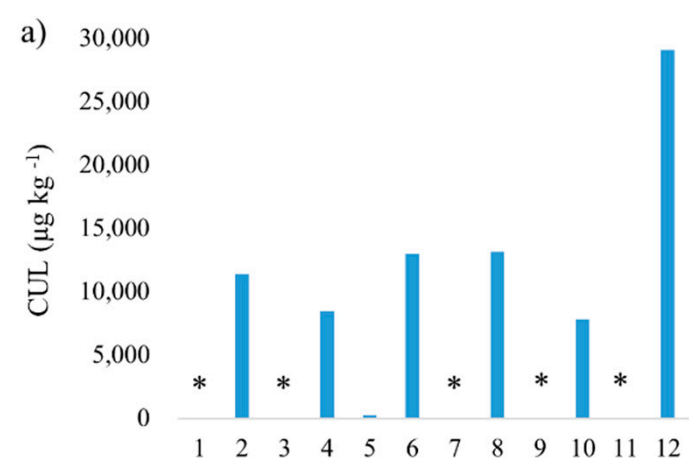

c) 30,000

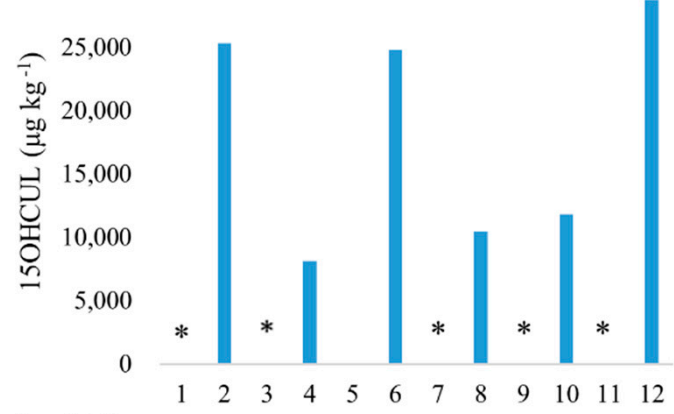

e) 5,000

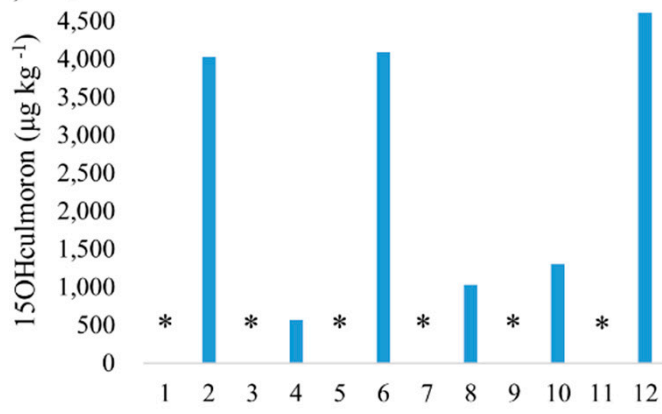

g) 25,000

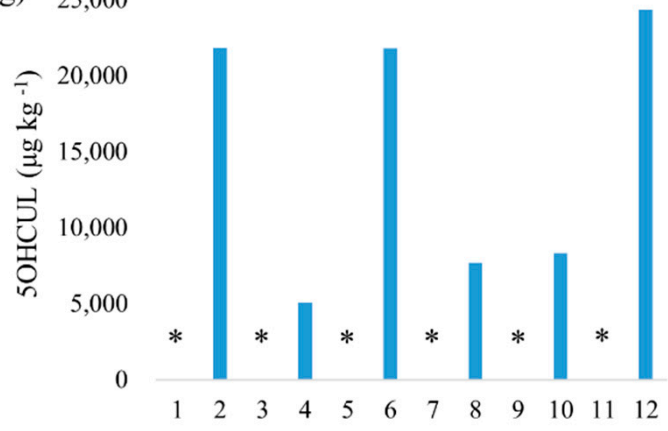

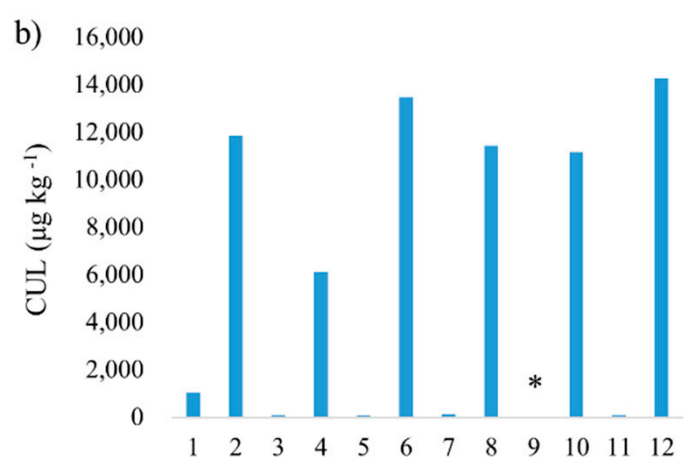

d) 30,000

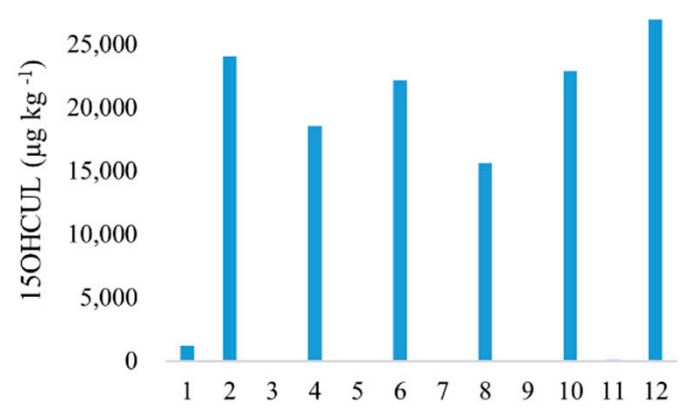

f) 3,000
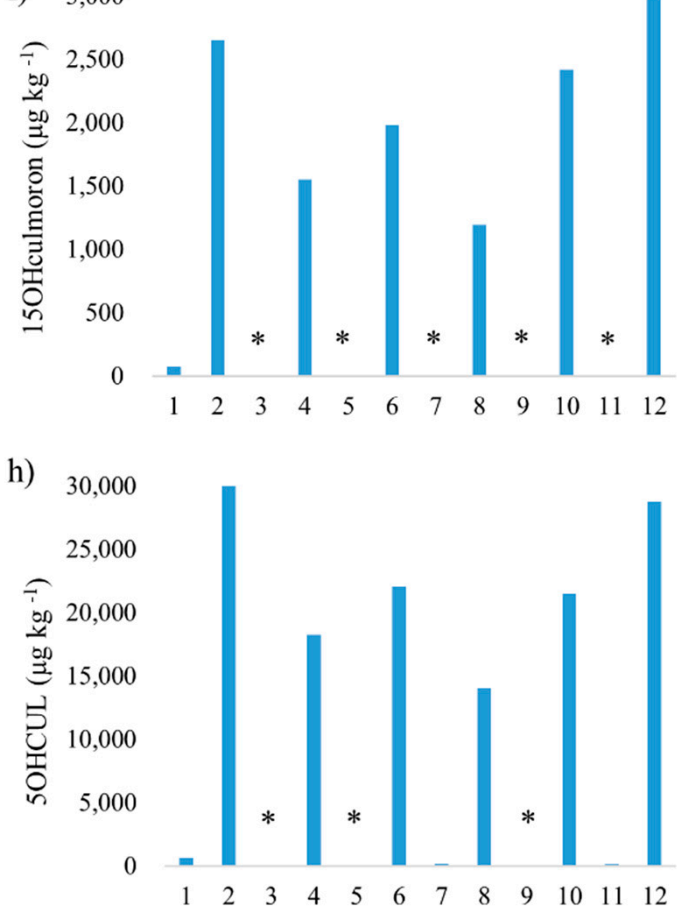

$$
\begin{array}{ll}
1 \text { - El Nino - naturally infected } & 7 \text { - Vulkan - naturally infected } \\
2 \text { - El Nino - inoculated } & 8 \text { - Vulkan - inoculated } \\
3 \text { - Galloper - naturally infected } & 9 \text { - Kraljica - naturally infected } \\
\text { 4 - Galloper - inoculated } & 10 \text { - Kraljica - inoculated } \\
5 \text { - Tika Taka - naturally infected } & 11 \text { - Golubica - naturally infected } \\
\text { 6 - Tika Taka - inoculated } & 12 \text { - Golubica - inoculated }
\end{array}
$$

Figure 4. Concentrations of culmorin (CUL) (a,b), 15-hydroxyculmorin (15OHCUL) (c,d), 15-hydroxyculmoron (15OHculmoron) (e,f) and 5-hydroxyculmorin (5OHCUL) (g,h) in artificially inoculated and naturally infected samples at Osijek $(\mathbf{a}, \mathbf{c}, \mathbf{e}, \mathbf{g})$ and Tovarnik $(\mathbf{b}, \mathbf{d}, \mathbf{f}, \mathbf{h})$. The asterisk $\left(^{*}\right)$ indicates that measured values are below LOD values. 
a) 14,000

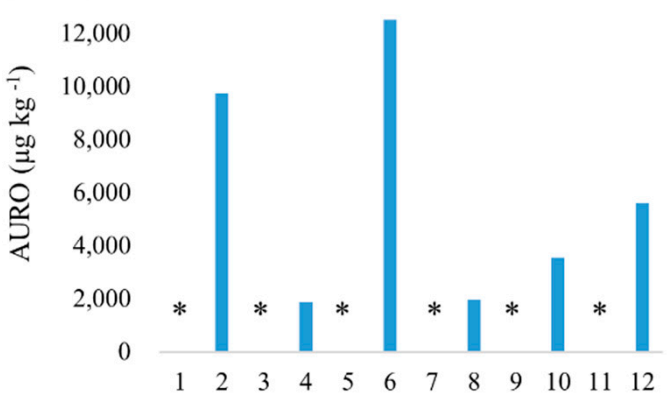

c) 1,200

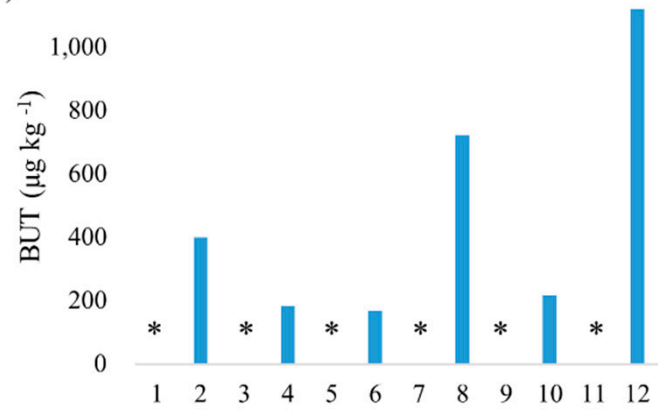

e) 1,400

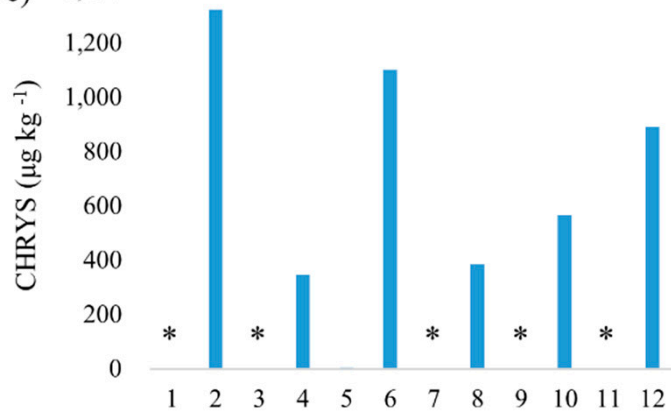

g) 3,000

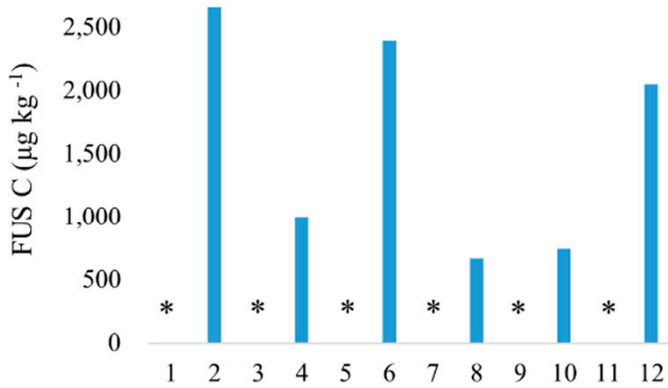

b) 70,000

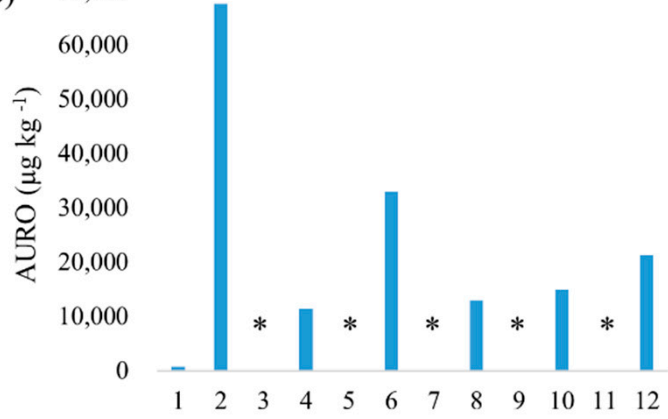

d)

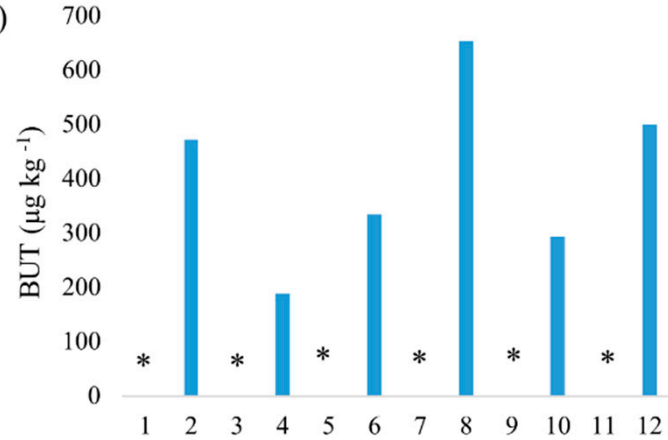

f) 1,200

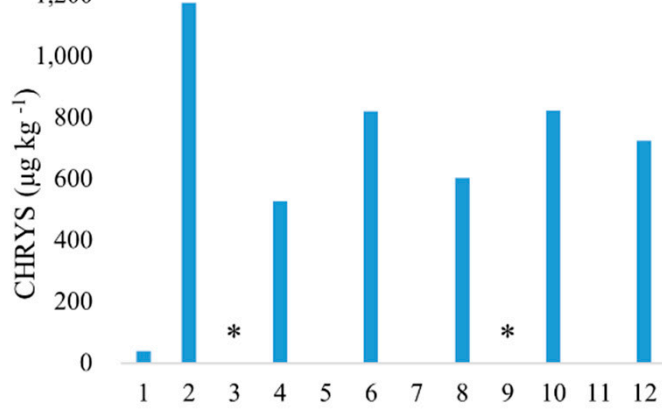

h) 7,000

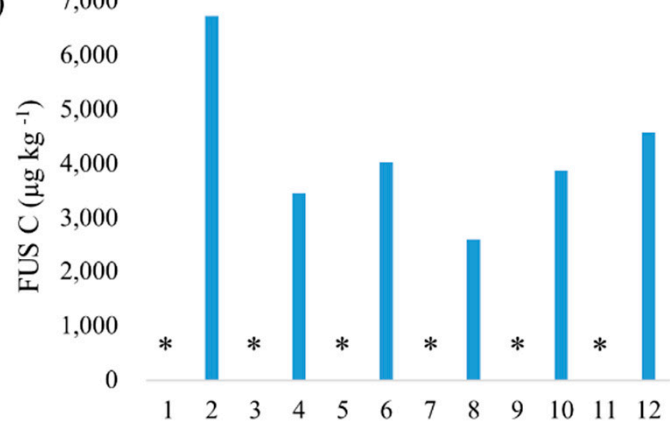

1 - E1 Nino - naturally infected 2 - El Nino - inoculated

3 - Galloper - naturally infected

4 - Galloper - inoculated

5 - Tika Taka - naturally infected

6 - Tika Taka - inoculated
7 - Vulkan - naturally infected

8 - Vulkan - inoculated

9 - Kraljica - naturally infected

10 - Kraljica - inoculated

11 - Golubica - naturally infected

12 - Golubica - inoculated

Figure 5. Concentrations of aurofusarin (AURO) (a,b), butenolide (BUT) (c,d), chrysogin (CHRYS) (e,f) and fusarin C (FUS C) $(\mathbf{g}, \mathbf{h})$ in artificially inoculated and naturally infected samples at Osijek $(\mathbf{a}, \mathbf{c}, \mathbf{e}, \mathbf{g})$ and Tovarnik $(\mathbf{b}, \mathbf{d}, \mathbf{f}, \mathbf{h})$. The asterisk $\left(^{*}\right)$ indicates that measured values are below LOD values. 


\subsection{ANOVA and Correlation Analysis}

Analysis of variance (ANOVA) revealed significant differences in 13 investigated mycotoxins among two treatments $(p<0.001, p<0.01)$. Non-significant difference was found between varieties and locations for the most mycotoxins, except for 3-acetyldeoxynivalenol $(3 \mathrm{ADON})$, nivalenol (NIV) and fusarin $\mathrm{C}$ between locations. Moreover, significant differences were recorded between varieties for NIV $(p<0.01)$ (Table 2).

Correlation analysis showed no statistically significant relationship between the amount of FHB symptoms (Type I and general resistance) and DON contamination although correlation was moderately positive at both locations, Osijek and Tovarnik $(\mathrm{r}=0.77$, $p<0.05$ ) (Supplementary Tables S10 and S11). At Osijek, NIV, hydroxyculmorins and 15-hydroxyculmoron occurred concomitantly with DON ( $\mathrm{r}=0.88, p<0.05 ; \mathrm{r}=0.94, p<0.01$; $\mathrm{r}=0.88, p<0.05$ and $\mathrm{r}=0.94, p<0.01$, respectively) (Supplementary Table S10), while at Tovarnik DON was in high positive correlation with enumerated mycotoxins including 3 -ADON $(\mathrm{r}=0.94, p<0.01 ; \mathrm{r}=0.94, p<0.01 ; \mathrm{r}=0.94, p<0.01 ; \mathrm{r}=0.94, p<0.01 ; \mathrm{r}=0.94$, $p<0.01 ; r=0.94, p<0.01$, respectively) (Supplementary Table S11). There was also high positive relationship between Type I resistance, general resistance and level of aurofusarin at Tovarnik ( $\mathrm{r}=0.83, p<0.05$ and $\mathrm{r}=0.89, p<0.05$, respectively) (Supplementary Table S11). 
Table 2. Analysis of variance (ANOVA) for 13 analyzed Fusarium metabolites.

\begin{tabular}{|c|c|c|c|c|c|c|c|c|c|c|c|c|c|c|}
\hline \multirow{2}{*}{$\begin{array}{l}\text { Source of } \\
\text { Variation }\end{array}$} & \multirow{2}{*}{ Df } & \multicolumn{13}{|c|}{ F-Value } \\
\hline & & DON & D3G & 3ADON & NIV & ZEN & CUL & $\begin{array}{c}15- \\
\text { OHCUL }\end{array}$ & $\begin{array}{c}15-\mathrm{OH} \\
\text { Culmoron }\end{array}$ & $\begin{array}{c}5- \\
\text { OHCUL }\end{array}$ & AURO & BUT & CHRYS & FUS C \\
\hline Location & 1 & $3.43 \mathrm{~ns}$ & $3.52 \mathrm{~ns}$ & 4.93 * & 8.98 ** & $1.46 \mathrm{~ns}$ & $0.51 \mathrm{~ns}$ & $1.1 \mathrm{~ns}$ & $0.42 \mathrm{~ns}$ & $3.68 \mathrm{~ns}$ & $4.71 \mathrm{~ns}$ & $0.17 \mathrm{~ns}$ & $0.01 \mathrm{~ns}$ & $9.16^{* *}$ \\
\hline Treatment & 1 & $87.93^{* * *}$ & $105.19^{* * *}$ & $54.8^{* * *}$ & 13.3 ** & $18.07^{* * *}$ & $63.33^{* * *}$ & $124.29^{* * *}$ & $43.92 * * *$ & $84.31^{* * *}$ & $11.25^{* * *}$ & $33.95^{* * *}$ & $98.56^{* * *}$ & $44.54^{* * *}$ \\
\hline Variety & 5 & $2.14 \mathrm{~ns}$ & $2.03 \mathrm{~ns}$ & $1.89 \mathrm{~ns}$ & $4.62 * *$ & $1.26 \mathrm{~ns}$ & $1.65 \mathrm{~ns}$ & $2.13 \mathrm{~ns}$ & $1.85 \mathrm{~ns}$ & $2.07 \mathrm{~ns}$ & $1.12 \mathrm{~ns}$ & $1.97 \mathrm{~ns}$ & $2.66 \mathrm{~ns}$ & $1.03 \mathrm{~ns}$ \\
\hline
\end{tabular}

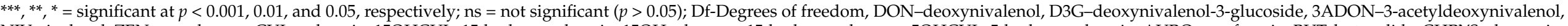

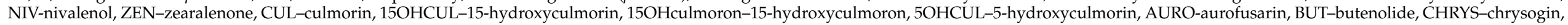
FUS C-fusarin C. 


\section{Discussion}

The study has focused on the effect of epidemic FHB conditions on the production of a range of metabolites originated either from the naturally contaminating mycobiota, or from inoculation by Fusarium graminearum and F. culmorum isolates. Furthermore, this study extended the investigation beyond the well-known mycotoxins to a range of fungal secondary metabolites accumulated in wheat grains. According to previous findings, fungal secondary metabolites commonly found in wheat grains are deoxynivalenol (DON), a type $B$ trichothecene, and zearalenone (ZEN), while predominant species producing these mycotoxins in Europe are found to be F. graminearum, F. culmorum and F. avenaceum [30]. Given the fact that $F$. graminearum widely occurs in Europe, it is also predominantly found in Croatia [31]. However, many Fusarium metabolites are far less investigated than DON and ZEN [32] and therefore are not subject to legislation and regular monitoring. Both emerging mycotoxins and modified forms represent a new issue for food contamination [33].

The mycotoxigenic fungi produce several secondary metabolites at the time [34]. Therefore, this study reports the occurrence of 13 Fusarium metabolites and their concentrations in the wheat grains of six artificially inoculated as well as in naturally infected (field grown) winter wheat varieties (El Nino, Galloper, Tika Taka, Vulkan, Kraljica and Golubica). The combined use of resistant wheat varieties, fungicides, and specific management practices can reduce part of the Fusarium head blight (FHB) losses [35]. Therefore, the impact of fungicides in the current research was omitted, as well as the influence of management practice, as field experiments were done according to standard agronomical procedures. Considering that precipitation levels between two locations at which the experiment was held differed with Tovarnik having a higher precipitation rate and higher temperatures, levels of Fusarium metabolites studied were higher at Tovarnik, compared to Osijek. This is in accordance with previous reports where warm and humid conditions at and shortly after anthesis favour FHB [36]. Humidity determines the intensity of the disease, while precipitation determines inoculum levels [37]. In addition, wheat varieties in treatment with inoculation with Fusarium fungi were evaluated for Type I (initial) and general FHB resistance in the field conditions prior to harvest by calculating AUDPC.

\subsection{Deoxynivalenol, Deoxynivalenol-3-glucoside and 3-Acetyldeoxynivalenol}

Taking into account only proved Fusarium mycotoxins and not all metabolites studied, the current research was in accordance with previous studies which reported that DON is the most abundant mycotoxin in wheat grains [38,39]. In this study, varieties with higher initial susceptibility (El Nino, Tika Taka and Golubica) accumulated DON even in naturally infected samples. The average level of DON in naturally infected winter wheat plants (control samples) at location Tovarnik did not exceed the legal limit set by EU (1 $\left.250 \mu \mathrm{g} \mathrm{kg}^{-1}\right)$ for unprocessed cereals [40] while at Osijek in naturally infected samples it was not found. The same results were previously reported where in randomly selected wheat samples from natural infection in Croatia, DON levels were below this threshold [41]. However, in the current research FHB artificially inoculated plants exceeded maximum levels for DON contamination 10-fold at Osijek and 15-fold at Tovarnik. As DON significantly correlated with few investigated mycotoxins, it can be concluded that DON content can be used in the selection for FHB resistance and could potentially participate in lowering total toxicity.

Deoxynivalenol-3-glucoside (D3G) is one of the main DON metabolites known as "modified mycotoxin" [42]. After ingestion it can be hydrolysed to DON [43,44]. D3G was present in Fusarium infected samples at both locations, while in naturally infected plants it was observed in susceptible varieties El Nino, Tika Taka and Golubica only at Tovarnik. Concentrations observed in the current research were similar to previous studies reporting the occurrence of DON and D3G in durum wheat in Italy [45]. Previously it was concluded that D3G usually comes in lower concentrations, compared to concentrations of DON [46].

3-acetyldeoxynivalenol (3ADON) was observed in Fusarium infected samples at Osijek as well as at Tovarnik. At Tovarnik it was also found in naturally infected samples in 
susceptible El Nino variety. In some researches, $3 \mathrm{ADON}$ was among the most abundant mycotoxins $[47,48]$, which was not the case in the current research.

Correlations between DON and 3ADON were highly significant at Tovarnik which is in accordance with the previous research [49] where DON highly correlated with 3ADON in barley samples. Also, this correlation was expected in the current research as DONproducing strains with the 3-acetylated precursor are common in Europe [50]. The more pronounced FHB symptoms the higher correlations between those mycotoxins occurred, where higher $3 \mathrm{ADON}$ production may be associated with elevated DON content. It was concluded that comparatively higher levels of gene expression may contribute to the higher levels of DON produced by 3ADON strains in infected grains [51]. Although there was not any significant correlation between DON and general and Type I resistance, it can be assumed that high level of DON occurred in varieties with different level of symptoms, as it was evidenced in previous studies [52] reporting that the occurrence of high humidity post-anthesis produced late infections, with a high level of DON, but low level of FHB symptoms.

\subsection{Nivalenol and Zearalenone}

The obtained results showed that nivalenol (NIV) at Osijek was represented only in varieties with high initial susceptibility (El Nino, Tika Taka and Golubica) in artificially inoculated samples. At Tovarnik, it was found in all Fusarium infected plants while in naturally infected samples it was observed only in susceptible variety Golubica. This is in accordance with previous studies [53] where NIV was found only in one naturally infected wheat sample. This was expected for Fusarium infected samples as both F. graminearum and F. culmorum produce NIV at all tested temperatures between 10 and $30^{\circ} \mathrm{C}$ [54]. In the previous research the highest concentration of NIV in the organic cereal samples was $106 \mu \mathrm{g} \mathrm{kg}^{-1}$ [55], while the concentration of NIV in the current study was lower in the Fusarium infected as well as in the naturally infected samples.

Zearalenone (ZEN) concentrations were the lowest of all Fusarium metabolites studied at both locations and did not exceed risk threshold levels of $100 \mu \mathrm{g} \mathrm{kg}^{-1}$ for unprocessed cereals other than maize [40] in artificially inoculated nor in naturally infected samples. Our findings are in accordance with previous studies which showed that concentrations of ZEN found in wheat mostly do not exceed $50 \mu \mathrm{g} \mathrm{kg}^{-1}$ [32,56]. As expected, at Osijek ZEN was found only in inoculated samples while at Tovarnik in naturally infected plants it was observed only in susceptible variety El Nino in negligible concentration. Although there were not any significant correlations between DON and ZEN, it was previously concluded that ZEN is often co-produced with DON by Fusarium spp. such as F. graminearum [57]. For example, in another study where large European screening for Fusarium mycotoxins was obtained, ZEN was found in $32 \%$ of approximately 5000 samples of cereal grains and products tested [58].

\subsection{Culmorin, 15-Hydroxyculmorin, 15-Hydroxyculmoron and 5-Hydroxyculmorin}

In the novel time, there are numerous evidence for culmorin (CUL) being an "emerging mycotoxin". It is confirmed that CUL can inhibit the reaction of glucuronidation and thus increase the toxicity of DON $[15,22]$. Wheat samples with higher DON concentration contained elevated levels of CUL which implies that CUL can have a possible role in Fusarium virulence. Previously, it was reported about interactions between CUL and DON and its toxicity in growing pigs [59]. Furthermore, synergism between CUL and trichothecenes in plants occurred [60]. In Fusarium infected samples varieties with higher initial susceptibility (El Nino, Tika Taka and Golubica) accumulated CUL in much higher concentrations than other varieties. In Norway there was a concentration of $100 \mu \mathrm{g} \mathrm{kg}^{-1}$ detected in wheat [61].

Except for CUL, in the analysed samples also occurred 15-hydroxyculmorin, 15hydroxyculmoron and 5-hydroxyculmorin. Our study was partially in accordance with other researches which showed that in samples artificially inoculated with F. culmorum 
15-hydroxyculmorin was the most abundant derivative of CUL and 5-hydroxyculmorin second abundant [23] as in the current research at Osijek, while at Tovarnik this was opposite with the most abundant 5-hydroxyculmorin and second 15-hydroxyculmorin. Moreover, in the above-mentioned study in naturally infected samples, CUL was the major metabolite, while in the current research in naturally infected samples CUL and its derivatives were found only at Tovarnik where the major metabolite was 15-hydroxyculmorin. The current study is in accordance with research which reporting that in naturally infected samples of wheat in Croatia concentration of CUL and 15-hydroxyculmorin is at a similar range as the concentration of DON thus implying that DON is correlated with CUL and hydroxyculmorins [62]. In addition to that at Tovarnik, CUL was in a positive significant correlation with AUDPC for general resistance thus implying that CUL role in Fusarium virulence is more pronounced in increased FHB pressure.

\subsection{Aurofusarin, Butenolide, Chrysogin and Fusarin C}

Fusarium metabolites aurofusarin, butenolide, chrysogin and fusarin $C$ observed in this study are recently discovered and therefore far less investigated than others [39]. Under increased FHB pressure, aurofusarin was observed in all varieties at both, Osijek and Tovarnik, while in naturally infected samples it was observed only in Tovarnik in susceptible variety El Nino. In naturally infected samples of wheat aurofusarin was found in wheat in levels up to $4200 \mu \mathrm{g} \mathrm{kg}^{-1}$ [63]. At Osijek, the average level of aurofusarin was in accordance with previous study [64], while at Tovarnik it was observed in much higher concentrations implying that there is a certain connection between the production of major Fusarium mycotoxins and pigments. There was an even higher concentration of aurofusarin detected up to $140,000 \mathrm{\mu g} \mathrm{kg}^{-1}$ in Italian samples of durum wheat [65] than in the current research at Tovarnik. Although previous studies report aurofusarin and rubrofusarin accompanied by one another [66], in the current research rubrofusarin was not observed. According to previous studies there is the genetic and biosynthetic origin of aurofusarin and both DON and ZEN [67].

Determined levels of butenolide and chrysogin were lower than those previously reported [64]. However, results are in accordance with the research where fusarin $C$ and chrysogine concentrations were higher in the wheat with F. graminearum treatments in contrast to the naturally stored wheat [68]. Higher concentration of fusarin C (average level 40,042 $\mathrm{mg} \mathrm{kg}^{-1}$ ), chrysogin (average level $39 \mathrm{mg} \mathrm{kg}^{-1}$ ) and butenolide (7300 $\mathrm{mg} \mathrm{kg}^{-1}$ ) were obtained in durum wheat in the fields with natural infection [65], while aurofusarin (average level $76,875 \mathrm{mg} \mathrm{kg}^{-1}$ ) was at a similar level as in the present study. Butenolide and fusarin $C$ were expected to be detected in the current research because both F. graminearum and F. culmorum have the ability to produce them [17]. Furthermore, current research revealed high positive correlation between chrysogin and aurofusarin, which was expected, as chrysogin is also pigment produced by Fusarium sp. [69].

\section{Conclusions}

This study performed at two different locations indicated that winter wheat samples with higher deoxynivalenol (DON) concentration contained elevated levels of culmorin (CUL) and hydroxyculmorins, showing that CUL can have a possible role in Fusarium virulence, which became more pronounced in elevated infection with Fusarium fungi. Since DON significantly correlated with few investigated metabolites, it can be assumed that DON can participate in lowering total toxicity. Furthermore, according to elevated aurofusarin levels, it is also assumed that there is a certain connection between the production of major Fusarium mycotoxins and pigments under increased FHB pressure. As the impact of some fungal secondary metabolites on food and feed safety, i.e., human and animal health is still unclear, it is of great importance to investigate their toxicity, as well as consequently regulate maximal allowed concentration for specific food and feed. Furthermore, possible synergistic effects between certain metabolites need to be investigated more closely as they could interact together thus giving total toxicity. An inevitable practical conclusion of 
this manuscript is also information about the genetic resistance of winter wheat varieties investigated which will be useful for future risk assessment, considering FHB pressure and consequently mycotoxin production.

Supplementary Materials: The following are available online at https:/ / www.mdpi.com/article/10 .3390/agronomy11112239/s1, Figure S1: Climate diagram for May 2020 at Osijek. Figure S2: Climate diagram for May 2020 at Tovarnik. Table S1: Daily precipitation $(\mathrm{mm})$ during May, June and July at Osijek in 2020. Table S2: Daily precipitation (mm) during May, June and July at Tovarnik in 2020. Table S3: Daily temperatures $\left({ }^{\circ} \mathrm{C}\right)$ during May, June and July at Osijek in 2020. Table S4: Daily temperatures $\left({ }^{\circ} \mathrm{C}\right)$ during May, June and July at Tovarnik in 2020. Table S5: Apparent recovery values, LOD values and LOQ values for 13 Fusarium secondary metabolites analyzed. Table S6: Amounts of Fusarium secondary metabolites in naturally infected samples at Osijek. Table S7: Amounts of Fusarium secondary metabolites in samples inoculated with Fusarium fungi at Osijek. Table S8: Amounts of Fusarium secondary metabolites in naturally infected samples at Tovarnik. Table S9: Amounts of Fusarium secondary metabolites in samples inoculated with Fusarium fungi at Tovarnik. Table S10: Correlation analysis between metabolite accumulation and the area under the disease progress curve (AUDPC) for general and Type I (initial) resistance at Osijek. Table S11: Correlation analysis between metabolite accumulation and the area under the disease progress curve (AUDPC) for general and Type I (initial) resistance at Tovarnik.

Author Contributions: K.S. wrote the manuscript and interpreted the results. T.K., A.L., J.B. and G.D. interpreted the results, done statistical analysis and revised the manuscript. M.S. and R.K. performed mycotoxin research and revised the manuscript. V.S. conceived the study, performed the field experiments, and revised the manuscript. All authors have read and agreed to the published version of the manuscript.

Funding: This research was co-financed by the European Union through the European Regional Development Fund-the Competitiveness and Cohesion Operational Programme for grant number KK.01.1.1.04.0067.

Conflicts of Interest: The authors declare no conflict of interest.

\section{References}

1. Shewry, P.R. Wheat. J. Exp. Bot. 2009, 60, 1537-1553. [CrossRef]

2. Osborne, L.E.; Stein, J.M. Epidemiology of Fusarium head blight on small-grain cereals. Int. J. Food Microbiol. 2007, 119, 103-108. [CrossRef] [PubMed]

3. Popovski, S.; Celar, F.A. The impact of environmental factors on the infection of cereals with Fusarium species and mycotoxin production-A review. Acta Agric. Slov. 2013, 101, 105-116. [CrossRef]

4. Spanic, V.; Marcek, T.; Abicic, I.; Sarkanj, B. Effects of Fusarium Head Blight on Wheat Grain and Malt Infected by Fusarium culmorum. Toxins 2018, 10, 17. [CrossRef] [PubMed]

5. Beccari, G.; Arellano, C.; Covarelli, L.; Tini, F.; Sulyok, M.; Cowger, C. Effect of wheat infection timing on Fusarium head blight causal agents and secondary metabolites in grain. Int. J. Food Microbiol. 2019, 290, 214-225. [CrossRef]

6. Spanic, V.; Lemmens, M.; Drezner, G. Morphological and molecular identification of Fusarium species associated with head blight on wheat in East Croatia. Eur. J. Plant. Pathol. 2010, 128, 511-516. [CrossRef]

7. Desjardins, A.E. Fusarium Mycotoxins: Chemistry, Genetics, and Biology, 1st ed.; American Phytopathological Society (APS Press): St. Paul, MN, USA, 2006.

8. Mielniczuk, E.; Skwaryło-Bednarz, B. Fusarium Head Blight, Mycotoxins and Strategies for Their Reduction. Agronomy 2020, 10, 509. [CrossRef]

9. Xu, X.M.; Nicholson, P.; Thomsett, M.A.; Simpson, D.; Cooke, B.M.; Doohan, F.M.; Brennan, J.; Monaghan, S.; Moretti, A.; Mule, G.; et al. Relationship Between the Fungal Complex Causing Fusarium Head Blight of Wheat and Environmental Conditions. Phytopathology 2008, 98, 69-78. [CrossRef] [PubMed]

10. Czaban, J.; Wróblewska, B.; Sułek, A.; Mikos-Szymańska, M.; Boguszewska, E.; Podolska, G.; Nieróbca, A. Colonisation of winter wheat grain by Fusarium spp. and mycotoxin content as dependent on a wheat variety, crop rotation, a crop management system and weather conditions. Food Addit. Contam. Part A 2015, 32, 874-910. [CrossRef]

11. Bernhoft, A.; Torp, M.; Clasen, P.-E.; Løes, A.-K.; Kristoffersen, A.B. Influence of agronomic and climatic factors on Fusarium infestation and mycotoxin contamination of cereals in Norway. Food Addit. Contam. Part A 2012, 29, 1129-1140. [CrossRef]

12. Hope, R.; Aldred, D.; Magan, N. Comparison of environmental profiles for growth and deoxynivalenol production by Fusarium culmorum and F. graminearum on wheat grain. Lett. Appl. Microbiol. 2005, 40, 295-300. [CrossRef] [PubMed]

13. Mesterhazy, A. Types and components of resistance to Fusarium head blight of wheat. Plant. Breed 1995, 114, 377-386. [CrossRef] 
14. Cuomo, C.A.; Güldener, U.; Xu, J.-R.; Trail, F.; Turgeon, B.G.; Di Pietro, A.; Walton, J.D.; Ma, L.-J.; Baker, S.; Rep, M.; et al. The Fusarium graminearum Genome Reveals a Link Between Localized Polymorphism and Pathogen Specialization. Science 2007, 317, 1400-1402. [CrossRef]

15. Woelflingseder, L.; Warth, B.; Vierheilig, I.; Schwartz-Zimmermann, H.; Hametner, C.; Nagl, V.; Novak, B.; Šarkanj, B.; Berthiller, F.; Adam, G.; et al. The Fusarium metabolite culmorin suppresses the in vitro glucuronidation of deoxynivalenol. Arch. Toxicol. 2019, 93, 1729-1743. [CrossRef]

16. Pestka, J.J. Deoxynivalenol: Mechanisms of action, human exposure, and toxicological relevance. Arch. Toxicol. 2010, 84, 663-679. [CrossRef]

17. Pasquali, M.; Giraud, F.; Brochot, C.; Cocco, E.; Hoffmann, L.; Bohn, T. Genetic Fusarium chemotyping as a useful tool for predicting nivalenol contamination in winter wheat. Int. J. Food Microbiol. 2010, 137, 246-253. [CrossRef]

18. Bretz, M.; Knecht, A.; Göckler, S.; Humpf, H.-U. Structural elucidation and analysis of thermal degradation products of the Fusarium mycotoxin nivalenol. Mol. Nutr. Food Res. 2005, 49, 309-316. [CrossRef] [PubMed]

19. Desjardins, A.; Proctor, R. Molecular biology of Fusarium mycotoxins. Int. J. Food Microbiol. 2007, 119, 47-50. [CrossRef] [PubMed]

20. Rai, A.; Das, M.; Tripathi, A. Occurrence and toxicity of a Fusarium mycotoxin, zearalenone. Crit. Rev. Food Sci. Nutr. 2020, 60, 2710-2729. [CrossRef]

21. Kovač, T.; Borišev, I.; Kovač, M.; Lončarić, A.; Kenjerić, F.Č.; Djordjevic, A.; Strelec, I.; Ezekiel, C.N.; Sulyok, M.; Krska, R.; et al. Impact of fullerol $\mathrm{C} 60(\mathrm{OH}) 24$ nanoparticles on the production of emerging toxins by Aspergillus flavus. Sci. Rep. 2020, 10, 725-810. [CrossRef]

22. Wipfler, R.; McCormick, S.P.; Proctor, R.H.; Teresi, J.M.; Hao, G.; Ward, T.J.; Alexander, N.J.; Vaughan, M.M. Ward Synergistic Phytotoxic Effects of Culmorin and Trichothecene Mycotoxins. Toxins 2019, 11, 555. [CrossRef] [PubMed]

23. Ghebremeskel, M.; Langseth, W. The occurrence of culmorin and hydroxy-culmorins in cereals. Mycopathology 2001, 152, 103-108. [CrossRef]

24. Farber, J.; Scott, P.; Fusarin, C. Fusarium, 1st ed.; Chełkowski, J., Ed.; Elsevier BV: Amsterdam, The Netherlands, 1989; Volume 2, pp. $41-52$.

25. Woelflingseder, L.; Adam, G.; Marko, D. Suppression of Trichothecene-Mediated Immune Response by the Fusarium Secondary Metabolite Butenolide in Human Colon Epithelial Cells. Front. Nutr. 2020, 7, 127. [CrossRef]

26. Jarolim, K.; Wolters, K.; Woelflingseder, L.; Pahlke, G.; Beisl, J.; Puntscher, H.; Braun, D.; Sulyok, M.; Warth, B.; Marko, D. The secondary Fusarium metabolite aurofusarin induces oxidative stress, cytotoxicity and genotoxicity in human colon cells. Toxicol. Lett. 2018, 284, 170-183. [CrossRef]

27. Zadoks, J.C.; Chang, T.T.; Konzak, C.F. A decimal code for the growth stages of cereals. Weed Res. 1974, 14, 415-421. [CrossRef]

28. Sulyok, M.; Stadler, D.; Steiner, D.; Krska, R. Validation of an LC-MS/MS-based dilute-and-shoot approach for the quantification of $>500$ mycotoxins and other secondary metabolites in food crops: Challenges and solutions. Anal. Bioanal. Chem. 2020, 412, 2607-2620. [CrossRef] [PubMed]

29. European Commission. COMMISSION DECISION of 12 August 2002 implementing Council Directive 96/23/EC concerning the performance of analytical methods and the interpretation of result. Off. J. Eur. Union L. 2002, 221, 8-36.

30. Bottalico, A.; Perrone, G. Toxigenic Fusarium species and mycotoxins associated with head blight in small-grain cereals in Europe. In Mycotoxins in Plant Disease, 1st ed.; Logrieco, A., Bailey, J.A., Corazza, L., Cooke, B.M., Eds.; Springer: Dordrecht, The Netherlands, 2002; pp. 611-624.

31. Spanic, V.; Lemmens, M.; Drezner, G.; Mesterházy, Á. Variability in components of fusarium head blight resistance among wheat genotypes. Cereal Res. Commun. 2013, 41, 420-430. [CrossRef]

32. Stanciu, O.; Banc, R.; Cozma, A.; Filip, L.; Miere, D.; Mañes, J.; Loghin, F. Occurence of Fusarium Mycotoxins in Wheat from Europe-A Review. Acta Univ. Cibiniensis. Ser. E Food Technol. 2015, 19, 35-60. [CrossRef]

33. Mortensen, A.; Granby, K.; Eriksen, F.D.; Cederberg, T.L.; Friis-Wandall, S.; Simonsen, Y.; Broesbøl-Jensen, B.; Bonnichsen, R. Levels and risk assessment of chemical contaminants in byproducts for animal feed in Denmark. J. Environ. Sci. Health Part B 2014, 49, 797-810. [CrossRef]

34. Streit, E.; Schatzmayr, G.; Tassis, P.; Tzika, E.; Marin, D.; Taranu, I.; Tabuc, C.; Nicolau, A.; Aprodu, I.; Puel, O.; et al. Current Situation of Mycotoxin Contamination and Co-occurrence in Animal Feed-Focus on Europe. Toxins 2012, 4, 788-809. [CrossRef]

35. Hollingsworth, C.R.; Motteberg, C.D.; Wiersma, J.V.; Atkinson, L.M. Agronomic and Economic Responses of Spring Wheat to Management of Fusarium Head Blight. Plant. Dis. 2008, 92, 1339-1348. [CrossRef]

36. Gautam, P.; Dill-Macky, R. Fusarium head blight development and trichothecene accumulation in point inoculated Fusarium infected wheat heads. World Mycotoxin J. 2012, 5, 45-55. [CrossRef]

37. Francl, L. Development of Fusarium head blight in relation to environment and inoculum. In Proceedings National Fusarium Head Blight Forum; Michigan State University, University Printing: East Lansing, MI, USA, 1998; pp. $26-27$.

38. Van der Fels-Klerx, H.; de Rijk, T.; Booij, C.; Goedhart, P.W.; Boers, E.; Zhao, C.; Waalwijk, C.; Mol, H.G.J.; van der Lee, T. Occurrence of Fusarium Head Blight species and Fusarium mycotoxins in winter wheat in the Netherlands in 2009. Food Addit. Contam. Part A 2012, 29, 1716-1726. [CrossRef] [PubMed]

39. Stanciu, O.; Juan, C.; Miere, D.; Loghin, F.; Mañes, J. Occurrence and co-occurrence of Fusarium mycotoxins in wheat grains and wheat flour from Romania. Food Control. 2017, 73, 147-155. [CrossRef] 
40. European Commission (EC). Regulation (EC) No 1881/2006 of 19 December 2006 setting maximum levels for certain contaminants in foodstuffs. Off. J. Eur. Union L. 2006, 364, 5-24.

41. Pleadin, J.; Vahčić, N.; Perši, N.; Ševelj, D.; Markov, K.; Frece, J. Fusarium mycotoxins' occurrence in cereals harvested from Croatian fields. Food Control. 2013, 32, 49-54. [CrossRef]

42. Kovač, M.; Šubarić, D.; Bulaić, M.; Kovač, T.; Šarkanj, B. Yesterday masked, today modified; what do mycotoxins bring next? Arch. Ind. Hyg. Toxicol. 2018, 69, 196-214. [CrossRef]

43. Berthiller, F.; Krska, R.; Domig, K.J.; Kneifel, W.; Juge, N.; Schuhmacher, R.; Adam, G. Hydrolytic fate of deoxynivalenol-3glucoside during digestion. Toxicol. Lett. 2011, 206, 264-267. [CrossRef] [PubMed]

44. Bryła, M.; Ksieniewicz-Woźniak, E.; Waśkiewicz, A.; Szymczyk, K.; Jędrzejczak, R. Natural Occurrence of Nivalenol, Deoxynivalenol, and Deoxynivalenol-3-Glucoside in Polish Winter Wheat. Toxins 2018, 10, 81. [CrossRef] [PubMed]

45. Dall'Asta, C.; Dall'Erta, A.; Mantovani, P.; Massi, A.; Galaverna, G. Occurrence of deoxynivalenol and deoxynivalenol-3-glucoside in durum wheat. World Mycotoxin J. 2013, 6, 83-91. [CrossRef]

46. Lemmens, M.; Steiner, B.; Sulyok, M.; Nicholson, P.; Mesterhazy, A.; Buerstmayr, H. Masked mycotoxins: Does breeding for enhanced Fusarium head blight resistance result in more deoxynivalenol-3-glucoside in new wheat varieties? World Mycotoxin J. 2016, 9, 741-754. [CrossRef]

47. Miedaner, T.; Reinbrecht, C.; Lauber, U.; Schollenberger, M.; Geiger, H.H. Effects of genotype and genotype-environment interaction on deoxynivalenol accumulation and resistance to Fusarium head blight in rye, triticale, and wheat. Plant. Breed. 2001, 120, 97-105. [CrossRef]

48. Zhao, J.; Cheng, T.; Xu, W.; Han, X.; Zhang, J.; Zhang, H.; Wang, C.; Fanning, S.; Li, F. Natural co-occurrence of multi-mycotoxins in unprocessed wheat grains from China. Food Control. 2021, 130, 108321. [CrossRef]

49. Tucker, J.R.; Badea, A.; Blagden, R.; Pleskach, K.; Tittlemier, S.A.; Fernando, W.G.D. Deoxynivalenol-3-Glucoside Content Is Highly Associated with Deoxynivalenol Levels in Two-Row Barley Genotypes of Importance to Canadian Barley Breeding Programs. Toxins 2019, 11, 319. [CrossRef]

50. Miller, J.D.; Greenhalgh, R.; Wang, Y.; Lu, M. Trichothecene Chemotypes of Three Fusarium Species. Mycologia 1991, 83, 121-130. [CrossRef]

51. Amarasinghe, C.C.; Fernando, W.G.D. Comparative Analysis of Deoxynivalenol Biosynthesis Related Gene Expression among Different Chemotypes of Fusarium graminearum in Spring Wheat. Front. Microbiol. 2016, 7, 1229. [CrossRef]

52. Cowger, C.; Arrellano, C. Plump Kernels with High Deoxynivalenol Linked to Late Gibberella zeae Infection and Marginal Disease Conditions in Winter Wheat. Phytopathology 2010, 100, 719-728. [CrossRef]

53. Spanic, V.; Zdunic, Z.; Drezner, G.; Sarkanj, B. The Pressure of Fusarium Disease and Its Relation with Mycotoxins in the Wheat Grain and Malt. Toxins 2019, 11, 198. [CrossRef]

54. Brennan, J.M.; Fagan, B.; van Maanen, A.; Cooke, B.M.; Doohan, F.M. Studies on in vitro Growth and Pathogenicity of European Fusarium fungi. Eur. J. Plant. Pathol. 2003, 109, 577-587. [CrossRef]

55. Juan, C.; Ritieni, A.; Mañes, J. Occurrence of Fusarium mycotoxins in Italian cereal and cereal products from organic farming. Food Chem. 2013, 141, 1747-1755. [CrossRef] [PubMed]

56. Klarić, M.; Cvetnić, Z.; Pepeljnjak, S.; Kosalec, I. Co-occurrence of Aflatoxins, Ochratoxin A, Fumonisins, and Zearalenone in Cereals and Feed, Determined by Competitive Direct Enzyme-Linked Immunosorbent Assay and Thin-Layer Chromatography. Arch. Ind. Hyg. Toxicol. 2009, 60, 427-434. [CrossRef] [PubMed]

57. Jestoi, M. EmergingFusarium-Mycotoxins Fusaproliferin, Beauvericin, Enniatins, and Moniliformin-A Review. Crit. Rev. Food Sci. Nutr. 2008, 48, 21-49. [CrossRef] [PubMed]

58. Gareis, M.; Zimmermann, C.; Schothorst, R.; Paulsch, W.; Vidnes, A.; Bergsten, C.; Paulsen, B.; Brera, C.; Miraglia, M.; Grossi, S.; et al. Collection of Occurrence Data of Fusarium toxins in Food and Assessment of Dietary Intake by the Population of EU Member States. 2001. Available online: http:/ / europa.eu.int/comm/food/fs/scoop/task3210.pdf (accessed on 20 May 2021).

59. Rotter, R.G.; Trenholm, H.L.; Prelusky, D.B.; Hartin, K.E.; Thompson, B.K.; Miller, J.D. A preliminary examination of potential interactions between deoxynivalenol (DON) and other selected Fusarium metabolites in growing pigs. Can. J. Anim. Sci. 1992, 72, 107-116. [CrossRef]

60. Weber, J.; Vaclavikova, M.; Wiesenberger, G.; Haider, M.; Hametner, C.; Fröhlich, J.; Berthiller, F.; Adam, G.; Mikula, H.; Fruhmann, P. Chemical synthesis of culmorin metabolites and their biologic role in culmorin and acetyl-culmorin treated wheat cells. Org. Biomol. Chem. 2018, 16, 2043-2048. [CrossRef]

61. Uhlig, S.; Eriksen, G.S.; Hofgaard, I.S.; Krska, R.; Beltrán, E.; Sulyok, M. Faces of a Changing Climate: Semi-Quantitative Multi-Mycotoxin Analysis of Grain Grown in Exceptional Climatic Conditions in Norway. Toxins 2013, 5, 1682-1697. [CrossRef] [PubMed]

62. Kifer, D.; Sulyok, M.; Jakšić, D.; Krska, R.; Klarić, M. Šegvić Fungi and their metabolites in grain from individual households in Croatia. Food Addit. Contam. Part. B 2021, 14, 98-109. [CrossRef]

63. Kotik, A.N.; Trufanova, V.A. Detection of naphtoquinone fusariotoxin aurofusarin in wheat. Mikol. Fitopatol. $1998,32,58-61$.

64. Spanic, V.; Katanic, Z.; Sulyok, M.; Krska, R.; Puskas, K.; Vida, G.; Drezner, G.; Šarkanj, B. Multiple Fungal Metabolites Including Mycotoxins in Naturally Infected and Fusarium-Inoculated Wheat Samples. Microorganisms 2020, 8, 578. [CrossRef] 
65. Beccari, G.; Colasante, V.; Tini, F.; Senatore, M.; Prodi, A.; Sulyok, M.; Covarelli, L. Causal agents of Fusarium head blight of durum wheat (Triticum durum Desf.) in central Italy and their in vitro biosynthesis of secondary metabolites. Food Microbiol. 2018, 70, 17-27. [CrossRef]

66. Frandsen, R.J.; Schütt, C.; Lund, B.W.; Staerk, D.; Nielsen, J.; Olsson, S.; Giese, H. Two Novel Classes of Enzymes Are Required for the Biosynthesis of Aurofusarin in Fusarium graminearum. J. Biol. Chem. 2011, 286, 10419-10428. [CrossRef]

67. Malz, S.; Grell, M.N.; Thrane, C.; Maier, F.J.; Rosager, P.; Felk, A.; Albertsen, K.S.; Salomon, S.; Bohn, L.; Schäfer, W.; et al. Identification of a gene cluster responsible for the biosynthesis of aurofusarin in the Fusarium graminearum species complex. Fungal Genet. Biol. 2005, 42, 420-433. [CrossRef] [PubMed]

68. Garcia-Cela, E.; Kiaitsi, E.; Medina, A.; Sulyok, M.; Krska, R.; Magan, N. Interacting Environmental Stress Factors Affects Targeted Metabolomic Profiles in Stored Natural Wheat and That Inoculated with F. graminearum. Toxins 2018, 10, 56. [CrossRef] [PubMed]

69. Wollenberg, R.D.; Saei, W.; Westphal, K.R.; Klitgaard, C.S.; Nielsen, K.L.; Lysøe, E.; Gardiner, D.M.; Wimmer, R.; Sondergaard, T.E.; Sørensen, J.L. Chrysogine Biosynthesis Is Mediated by a Two-Module Nonribosomal Peptide Synthetase. J. Nat. Prod. 2017, 80, 2131-2135. [CrossRef] [PubMed] 